\title{
Effects of Suramin on Human Lung Cancer Cell Lines
}

\author{
G.J. Rubio, H.M. Pinedo, J. Virizuela, J. van Ark-Otte and G. Giaccone
}

Suramin cytotoxicity was studied in a panel of human lung cancer cell lines by the MTT assay. The concentrations of suramin which induced $50 \%$ growth inhibition ( $\mathrm{IC}_{50}$ ) ranged from 130 to $3715 \mu \mathrm{M}$ for the cell lines growing in medium containing $10 \%$ fetal calf serum (FCS). In only one cell line was the $\mathrm{IC}_{50}$ at a concentration that can be reached in plasma of patients treated with suramin. Suramin was 18 and 3.3 times more cytotoxic on NCI-N417 cells growing in $2 \%$ FCS and in HITES serum-free medium, respectively, than growing in $10 \%$ FCS. No difference in suramin cytotoxicity was observed between small and non-small cell lung cancer cell lines. At the lower concentrations tested, suramin stimulated proliferation of the two small cell lung cancer cell lines, NCI-H187 and NCI-N417. Of several growth factors tested, none induced stimulation of growth in NCI-H187 and NCI-N417 cell lines, nor did they in any way alter the stimulatory effect of suramin. Cell counting, DNA flow cytometric analysis and Ki-67 staining confirmed a higher proliferative state in suramin-exposed NCI-H187 cells as compared with untreated cells. However, topoisomerase II- $\alpha$ gene expression remained unchanged, as assessed by northern blot analysis and immunostaining. Suramin had an inhibitory effect on topoisomerase II activity, as assessed by the kDNA decatenation assay, with an $\mathrm{IC}_{50}$ of approximately $40 \mu \mathrm{M}$. In conclusion, suramin has significant cytotoxic activity in a minority of human lung cancer cell lines, and it stimulates proliferation in some instances. The pleiotropic action of suramin observed should caution on the possibility of tumour acceleration in patients being treated with this drug.

Eur $\mathcal{F}$ Cancer, Vol. 31A, No. 2, pp. 244-251, 1995

\section{INTRODUCTION}

SURAMIN HAS been synthesised since the beginning of this century as an aminonaphthalene-sulphonic type urea, and has been used in the treatment of trypanosomiasis and onchocerciasis [1]. Recent studies showed that suramin has anti-tumoral activity in the treatment of several metastatic cancers such as renal cancer, adrenal carcinoma, lymphoma and prostate cancer [2]. Several mechanisms of suramin anti-tumour action have been described, including inhibition of activity of growth factors [3]. Suramin has been shown to inhibit the receptor binding of platelet-derived growth factor [4], basic fibroblastic growth factor, epidermal growth factor [5], transforming growth factors [6], insulin-like growth factors [7, 8] and cytokines [9]. Suramin can also interfere in processes involved in cell adhesion and migration $[10,11]$, as well as in different signal transduction pathways $[12,13]$, and it inhibits several nuclear and cytoplasmic enzymes [14, 15] and may induce cell differentiation [12]. Finally, it has recently been shown that topoisomerase II is a target of suramin action in Chinese hamster fibrosarcoma cells and that this may be important for the cytotoxic effect of the drug [16].

Lung cancer is the leading cause of cancer death in people over 35 years of age. Despite advances in cancer treatment,

Correspondence to $\mathrm{G}$. Giaccone.

G.J. Rubio, H.M. Pinedo, J. van Ark-Otte and G. Giaccone are at the Department of Oncology, Free University Hospital, Amsterdam, The Netherlands; and J. Virizuela is at the Hospital General, Huelva, Spain. Revised 17 Aug. 1994; accepted 5 Sep. 1994. mortality rates due to lung cancer are still nearly identical to incidence rates. Although small cell lung cancer (SCLC) is highly sensitive to chemotherapy at diagnosis, most patients relapse and die of chemorefractory disease. Non-small cell lung cancers (NSCLC) intrinsically respond poorly to chemotherapy. Lung tumours are known to produce a variety of growth factors, some acting in an autocrine loop [17]. New drugs are urgently needed in the treatment of lung cancer, with novel mechanisms of action. Because of its mechanisms of action, and in particular the inhibition of several growth factors important in the biology of lung cancer, suramin could be an interesting new agent to test in this malignancy.

We investigated and characterised the growth inhibitory effect of suramin in a variety of human lung cancer cell lines, and confirmed the inhibitory effect of suramin on human topoisomerase II. We also investigated whether the mechanism of growth inhibition of suramin is due to growth factor pathway interference.

\section{Cell lines}

\section{MATERIALS AND METHODS}

Cell lines were kindly provided by $\mathrm{Dr}$ A. Gazdar (NCI, Bethesda, Maryland, U.S.A.). Four human SCLC cell lines and three NSCLC cell lines were used (Table 1). All cell lines were cultured in RPMI 1640 medium (Gibco, Paisley, U.K.) supplemented with $10 \%$ fetal calf serum (FCS) (Sanbio, Uden, The Netherlands) at $37^{\circ} \mathrm{C}$ in a humid atmosphere with $5 \% \mathrm{CO}_{2}$. NCI-N417 cells were also adapted to grow in RPMI 1640 
Table 1. Suramin $\mathrm{IC}_{\text {so }}$ in human lung cancer cell lines

\begin{tabular}{lllcr}
\hline Cell line & Type & Medium & Doubling time $(\mathrm{h})$ & IC $_{\text {s0 }}(\mu M)$ \\
\hline NCI-H322 & Adenocarcinoma & RPMI + 10\% FCS & $72 \ddagger$ & 606 \\
NCI-H460 & Large cell carcinoma & RPMI + 10\% FCS & $20 \ddagger$ & 282 \\
NCI-H522 & Adenocarcinoma & RPMI + 10\% FCS & $24 \ddagger$ & 1281 \\
NCI-H69 & SCLC-c & RPMI + 10\% FCS & $70 \ddagger$ & 502 \\
NCI-H187 & SCLC-c & RPMI + 10\% FCS & $57 \ddagger$ & 3715 \\
NCI-H209 & SCLC-c & RPMI + 10\% FCS & $48 \ddagger$ & 130 \\
NCI-N417 & SCLC-v & RPMI + 10\% FCS & $31 \ddagger$ & 1713 \\
NCI-N417 & SCLC-v & RPMI + 2\% FCS & 31 & 97 \\
NCI-N417 & SCLC-v & HITES † & 51 & 515 \\
\hline
\end{tabular}

Drug treatments were for 4 days at $37^{\circ} \mathrm{C}$ on exponentially growing cells. The reported $\mathrm{IC}_{50}$ values are means of at least three independent experiments with S.D. $<25 \%$. ${ }^{*}$ Non-small cell lung cancer with neuroendocrine properties. † Serum-free medium as described [18]. $¥$ Data obtained from [20]. SCLC, small cell lung cancer; c, classic type; $v$, variant type; FCS, fetal calf serum.

medium supplemented with $2 \%$ FCS and in HITES serum-free medium (which contains hydrocortisone, insulin, transferrin, estradiol and selenium) [18].

\section{Cytotoxicity assay}

Growth inhibition was determined using the MTT assay with slight modifications [19], after 4 days of continuous exposure to different concentrations of suramin. Doubling times of all tested cell lines were also determined with the MTT assay, as described previously [20]. Briefly, cells were harvested from exponentially growing cultures, counted and plated in 96-well plates (Greiner Labortechnik, Solingen, Germany) $(100 \mu l$ cell suspension per well) at seeding densities which sustained exponential growth during the 4-day drug exposition of the assay. Only the number of cells was selected based on preliminary experiments, in order to have the best conditions supporting cell growth for the duration of the experiment. Twenty-four hours after plating, $100 \mu \mathrm{l}$ culture medium alone (control wells) or drug-containing medium was added to the wells, and $96 \mathrm{~h}$ after drug addition, $20 \mu \mathrm{l} \mathrm{MTT}(5 \mathrm{mg} / \mathrm{ml})$ was added. After $4 \mathrm{~h}$ incubation, the medium was removed, the formazan crystals were dissolved with $150 \mu \mathrm{l}$ dimethylsulphoxide containing $0.5 \% \mathrm{FCS}$, and the optical density (OD) was measured at $540 \mathrm{~nm}$ using a Titertek microplate reader (Multiskan MCC/3-40, Flow, Urvine, U.K.). Experiments were performed in triplicate. Suramin was purchased from Bayer (Leverkusen, Germany) and stored at $25 \mathrm{mM}$ dissolved in $0.9 \% \mathrm{NaCl}$ at $-20^{\circ} \mathrm{C}$ before use. The activity of several growth factors was also assayed in the NCI-H187 cell line and in NCI-N417 growing in 10\% FCS and HITES, which displayed marked stimulation of growth when exposed to relatively low suramin concentrations. Because albumin has been shown to avidly bind suramin [21], bovine serum albumin (BSA) $1.5 \mathrm{mg} / \mathrm{ml}$ was also investigated in cytotoxicity experiments with suramin in NCI-N417 cells growing in HITES medium. Length of exposure to growth factors and MTT evaluation were as described above. Epiderrnal growth factor (EGF) (Boehringer Mannheim B.V., Almere, The Netherlands) was used at final concentrations of 1,5 and $10 \mathrm{ng} / \mathrm{ml}$; granulocyte-macrophage colony-stimulating factor (GM-CSF) (Schering-Plough, Amstelveen, The Netherlands) wras used at final concentrations of 100 , 500 and $1000 \mathrm{pM}$; transforming growth factor $\beta 1$ (TGF- $\beta$ ) (Boehringer Mannheim E.V.) was used at final concentrations of $0.01,0.1$ and $1 \mathrm{ng} / \mathrm{ml}$; IGF-II (Gibco BRL, Breda, The
Netherlands) was used at final concentrations of 1,10 and $100 \mathrm{ng} / \mathrm{ml}$.

Proliferation and DNA flow cytometry of NCI-H187 cells

Growth curves of NCI-H187 cells in the presence or absence of $100 \mu \mathrm{M}$ suramin were determined by cell counting. Cells were harvested from exponential phase cultures, counted, seeded at $1 \times 10^{5} \mathrm{cells} / \mathrm{ml}$ in $25-\mathrm{cm}^{2}$ flasks (Nunc, Roskilde, Denmark) and cultured in RPMI 1640 medium supplemented with $10 \%$ FCS, $1 \%$ glutamine and gentamicin at $37^{\circ} \mathrm{C}$. Suramin or fresh medium (control flasks) was added $24 \mathrm{~h}$ after cells were seeded (day 0). Cells were harvested on days 1, 3 and 5, washed twice with ice-cold phosphate-buffered saline (PBS), fixed in $100 \%$ methanol and kept at $4^{\circ} \mathrm{C}$ until flow cytometric analysis. Cells were then washed with ice-cold PBS, counted $\left(2 \times 10^{6}\right.$ cells/ sample) and resuspended in RNase A $(0.5 \mathrm{mg} / \mathrm{ml}$ Tris buffer). After $30 \mathrm{~min}$ at $37^{\circ} \mathrm{C}$, each sample received an equal volume of a solution containing pepsin $(1 \mathrm{mg} / \mathrm{ml} 0.4 \% \mathrm{HCl})$ and was further incubated for $10 \mathrm{~min}$. Cells were stained with ethidium bromide $(20 \mu \mathrm{g} / \mathrm{ml})$ and Hoechst $33218(4 \mu \mathrm{g} / \mathrm{ml})$ stain diluted in PBS containing $1 \% \mathrm{BSA}$ at final $\mathrm{pH} 8$. The distribution of DNA per cell content was measured in at least 15000 cells/sample, using a fluorescence-activated cell sorter (FACSTAR ${ }^{\text {plus, }}$, BectonDickinson, Etten-Leur, The Netherlands) and DNA histograms were analysed using the DNA Cell Cycle Analysis SoftwareVersion C (Becton-Dickinson).

\section{Decatenation assay}

Topoisomerase II catalytic activity in nuclear extracts was tested by the decatenation assay [22]. Log-phase cells $\left(3 \times 10^{5}\right.$ cells $/ \mathrm{ml}$ ) were pelleted by centrifugation at $150 \mathrm{~g}$ for $10 \mathrm{~min}$ and washed three times with ice-cold PBS at $4^{\circ} \mathrm{C}$ and lysed with nuclear buffer containing $0.3 \%$ Triton $\mathrm{X}-100$. The nuclei pellet was resuspended in nuclear buffer $(150 \mathrm{mM} \mathrm{NaCl}, 1 \mathrm{mM}$ $\mathrm{KH}_{2} \mathrm{PO}_{4}, 5 \mathrm{mM} \mathrm{MgCl} 2.6 \mathrm{H}_{2} \mathrm{O}, 1 \mathrm{mM}$ EGTA, $1.0 \mathrm{mM}$ dithiotreitol and $1 \mathrm{mM}$ PMSF), pH 6.4 and an equal volume of nuclear buffer containing $\mathrm{NaCl}$ was added to obtain a final $\mathrm{NaCl}$ concentration of $0.35 \mathrm{M}$. Nuclear proteins were extracted for $30 \mathrm{~min}$ at $4^{\circ} \mathrm{C}$ and then the mixture was centrifuged at $16000 \mathrm{~g}$ for $20 \mathrm{~min}$ at $4^{\circ} \mathrm{C}$. Protein contentrations were determined by the method of Bradford. The enzyme solution was diluted with an equal volume of $87 \%$ glycerol. The reaction mixture contained $50 \mathrm{mM}$ Tris- $\mathrm{HCl}, 5 \mathrm{mM} \mathrm{MgCl}_{2}, 1 \mathrm{mM}$ 2-mercaptoethanol, 
$165 \mathrm{mM} \mathrm{KCl}, 1 \mathrm{mM} \mathrm{ATP}$ and $200 \mathrm{ng}$ of kinetoplast DNA (TopoGen, Ohio, U.S.A.). The reaction was initiated by the addition of the nuclear extracts and allowed to proceed at $37^{\circ} \mathrm{C}$ for $30 \mathrm{~min}$. Reactions were terminated with SDS, bromophenol blue and glyerol $(3 \%, 0.3 \%$ and $30 \% \mathrm{v} / \mathrm{v}$, respectively). The samples were electrophoresed in $1 \%$ agarose gels at $100 \mathrm{~V}$ for $2 \mathrm{~h}$ in Tris/borate/EDTA buffer at $\mathrm{pH}$ 8. The gels were then stained with ethidium bromide for $20 \mathrm{~min}$, destained and photographed by transillumination with uv light.

\section{Immunohistochemistry}

Cytospins of NCI-H187 cells after 4 days in culture ( 3 days of drug exposure) were dried overnight, fixed in acetone (paraformaldehyde plus acetic acid for topoisomerase II- $\alpha$ antibody) for $10 \mathrm{~min}$ at room temperature, washed in PBS and pre-incubated with normal rabbit serum at $1: 50$ in $1 \%$ PBS BSA for $10 \mathrm{~min}$. The indirect immunoperoxidase method was used. Blocking serum was drained off and the slides were incubated with the antibodies for $1 \mathrm{~h}$. Slides were then washed three times for $10 \mathrm{~min}$ with PBS and incubated for $15 \mathrm{~min}$ with undiluted affinity-purified rabbit anti-mouse biotinylated immunoglobulin (Zymed, California, U.S.A.). They were then conjugated to horseradish peroxidase streptavidin (Zymed) at 1: 500 in 1\% PBS BSA for $30 \mathrm{~min}$. All incubations were performed at room temperature in humidity chambers. Diaminobenzidine (Sigma Chemical Co., St Louis, Missouri, U.S.A.) was used as chromogen ( $5 \mathrm{mg}$ of DAB tetrahydrochloride in $100 \mathrm{ml}$ of PBS with $70 \mu \mathrm{l}$ of $30 \%$ hydrogen peroxide). Slides were rinsed in water, counterstained with haematoxylin, dehydrated, cleared and mounted. In negative control slides all steps were repeated, substituting the primary antibody with an irrelevant mouse monoclonal antibody (IgG). Frozen tonsil tissue sections were used as positive controls for $\mathrm{Ki}-67$ staining, while NCI-H322 cells were used as positive controls when topoisomerase antibodies were used. The $\mathrm{Ki}-67$ monoclonal antibody (Dako, Glostrup, Denmark) was used at $1: 10$ dilution; the monoclonal antibodies to human DNA topoisomerase I, II $\alpha$, and II $\beta[23,24]$ were generously provided by Dr G. Astaldi Ricotti (Pavia, Italy), and used at dilutions of $1: 25$, $1: 50,1: 25$, respectively.

\section{Northern blotting}

NCI-H187 cells of day 3 were trypsinised, resuspended in icecold culture medium, washed twice in PBS at $4^{\circ} \mathrm{C}$ and pelleted. Total RNA was extracted after lysis with guanidine isothiocyanate and centrifugation in a caesium chloride gradient [25]. Ten micrograms of total RNA were electrophoresed on a denaturing $1 \%$ agarose-formaldehyde gel and transferred to a nylon membrane (GeneScreenPlus; NEN Research Products, Boston, Massachusetts, U.S.A.). Prehybridisation, hybridisation with [ $\alpha$ ${ }^{32}$ P]dCTP-labelled cDNA probes (Random Primer Labelling System; Bethesda Research Laboratory, Rockville, Maryland, U.S.A.), and washing of the membrane were performed according to the vendor's instructions. A 1.8-kb human pl70 topoisomerase II- $\alpha$ cDNA fragment was kindly provided by Dr L.F. Liu (Baltimore, Maryland, U.S.A.) and a human cDNA GRP fragment was kindly provided by Dr B. Johnson (NCI-Navy, Bethesda, Maryland, U.S.A.). Differences in RNA loading were corrected by dividing the expression of the topoisomerase II $\alpha$ gene by that of the GAPDH gene (gift from C. Thiele, NCI, Bethesda, Maryland, U.S.A.) on the same northern blot, as described previously [20].

\section{RESULTS}

Suramin cytotoxicity in human lung cancer cell lines

A maximum of 28 -fold difference in cytotoxicity induced by suramin was observed, with NCI-H209 and NCI-H187, both SCLC cell lines, being the most sensitive and the most resistant cell lines, respectively. There was no differential sensitivity based on histological type or doubling time (Table 1). By observing the shape of the growth inhibitory curves, it appears that suramin has a more cytostatic than cytotoxic effect (Figures 1, 2, Table 1).

In NCI-N417 cells, adapted to grow in media containing different serum concentrations, there was a striking influence of serum concentration on the cytotoxicity that suramin induced in this cell line: $\mathrm{IC}_{50}$ values varied from $97 \mu \mathrm{M}$ in $\mathrm{RPMI}+2 \%$ FCS medium to $1713 \mu M$ in RPMI $+10 \%$ FCS medium. Interestingly, cells grown in HITES medium (serum-free) had

(a)

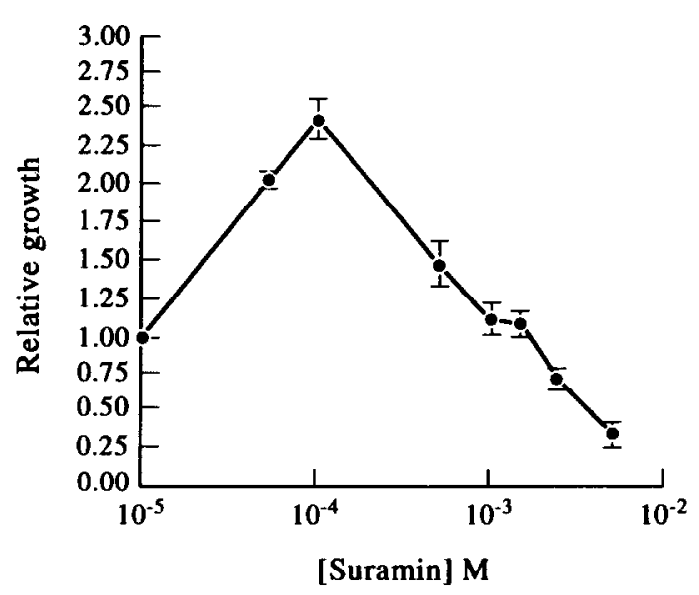

(b)

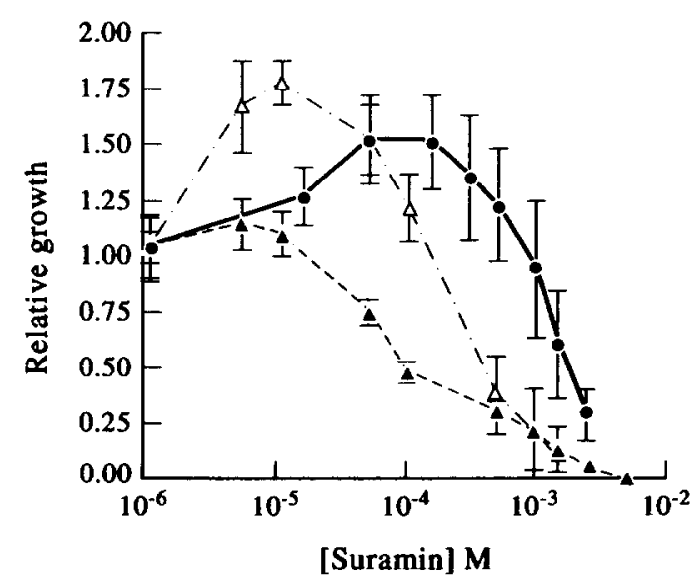

Figure 1. Suramin cytotoxicity curves in NCI-H187 (a) and NCIN417 (b) cell lines, as described in Material and Methods. Culture medium was RPMI $1640+10 \%$ FCS for NCI-H187. For NCI-N417 culture media were RPMI $1640+10 \%$ FCS (•), RPMI $1640+2 \%$ FCS $(\Delta)$ or HITES serum-free medium $(\triangle)$ [18]. The measured effect is defined as the ratio of cell growth relative to control cells growing without drug. The optical density value on day 0 (suramin addition) was approximately $30 \%$ (range 27-35) of the control values on day 4, for all cell lines tested. Experiments were repeated at least three times; error bars are S.D. 


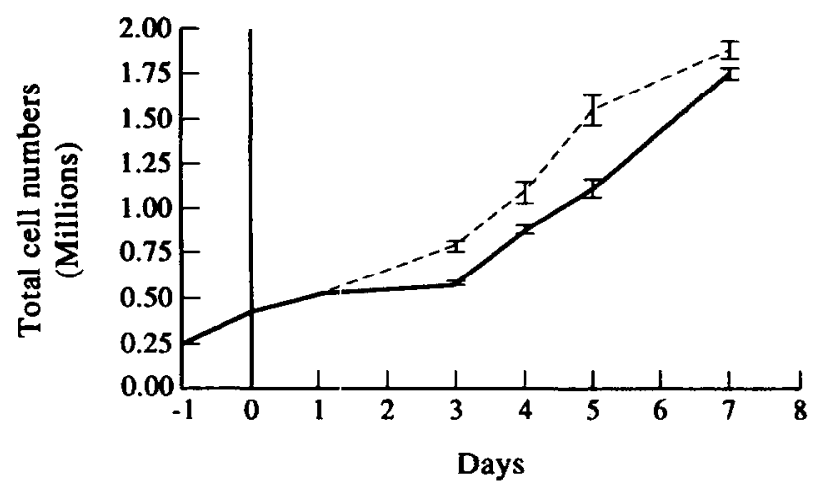

Figure 2. Growth curves of NCI-H187 cell line: control ( - ) and exposed to suramin $0.1 \mathrm{mM}(--)$. The cells were plated on day -1 and suramin was added on day 0 . Experiments were repeated three times; error bars are S.D.

an intermediate $\mathrm{IC}_{50}$ value of $515 \mu \mathrm{M}$. Doubling times of NCIN417 cells growing in serum-containing medium were the same, while cells growing in HITES serum-free medium had a longer doubling time (Table 1).

Although the cytotoxicity curves produced by suramin were concentration-dependent for most of the cell lines assessed, relatively low concentrations of suramin induced marked growth stimulation in two instances. The growth of the NCI-H187 cell line was stimulated to a maximum of 2.4 times over the control cells at drug concentrations between 5 and $250 \mu \mathrm{M}$ (Figure la). A less marked stimulatory effect was also observed in the NCIN417 cell line growing in HITES serum-free medium, where suramin concentrations ranging from 5 up to $100 \mu \mathrm{M}$ caused up to a 1.7 increase over the control cells (Figure 1b). Cells growing in $10 \%$ FCS were also stimulated (up to 1.5 times the control) at concentrations between 50 and $150 \mu \mathrm{M}$, while no stimulation of growth was observed in NCI-N417 cells grown in 2\% FCScontaining medium. The maximum stimulatory effect of suramin was therefore observed at lower suramin concentrations in NCI-N417 cells grown in HITES medium than that observed in cells grown in $10 \%$ FCS. Although the addition of BSA to NCIN417 cells growing in FITES did not influence the growth stimulatory pattern induced by suramin, it did cause a reduction of the steepness of the growth inhibitory curve, with a 5-fold increase in $\mathrm{IC}_{50}$ value, from $500 \mu \mathrm{M}$ to $1 \mathrm{mM}$ (data not shown).

We performed additional experiments in NCI-H187 cells, where the stimulatory effect was greatest. In a 7-day growth curve, a stimulation of cell proliferation was confirmed with a $100-\mu \mathrm{M}$ suramin concentration (Figure 2). The largest difference in cell counts was oloserved on day 5 , when the total cell number of suramin-exposed cultures was $40 \%$ higher than in control cultures $(P<0.05)$. The increased proliferation of NCIH187 cells exposed to suramin was accompanied by a rclative increase in S-phase cell population, as observed by DNA flow cytometric analysis (data not shown). We also performed immunostaining of NCI-H187 cytospins using the monoclonal antibody $\mathrm{Ki}-67$, a marker of cell proliferation. Cells were considered negative if the:y did not stain with the antibody, or displayed only spotted nuclear staining (nucleoli staining; see arrows, Figure 3B), as described previously [26]. While on day $3,50 \%$ of the control cells stained positive with $\mathrm{Ki}-67,80 \%$ of the suramin-treated cells stained positively (see arrows, Figure $3 \mathrm{C}$ ). Cells exposed to suramin had a more diffuse $\mathrm{Ki}-67$ nuclear staining, probably related to increased antigen synthesis diffusing from the nucleolar region [26].
Despite increased proliferation of the suramin exposed cells, the expression of the topoisomerase II- $\alpha$ gene was the same as in the untreated controls (not shown), as detected by northern analysis. This result was confirmed by immunohistochemistry with a specific topoisomerase II- $\alpha$ antibody to which most of the cells stained positive. In addition, most cells also displayed strong staining with antibodies against topoisomerase II- $\beta$ and topoisomerase I. While staining was homogenously nuclear for topoisomerase I and II- $\alpha$, staining for topoisomerase II- $\beta$ was mainly nucleolar, in agreement with prior reports $[23,24]$ (data not shown).

As increased proliferation after suramin exposure had been reported to be mediated by EGF in a cell line [27], we assessed whether EGF or other growth factors influenced growth of NCIH187 cells. None of the growth factors tested (EGF, GM-CSF, TGF- $\beta$, IGF-II) alone or in combination with suramin showed any effect on growth of NCI-H187, the cell line with the highest growth stimulation in the presence of suramin after 4 days of incubation (Figure 4, and data not shown). In addition, NCIH417 cells, known to express the receptor for EGF [28], growing in $10 \%$ FCS or in HITES, also did not display any changes in proliferation after exposure to EGF or IGF-II alone or in coincubation with suramin (data not shown).

Finally, we assesed whether suramin exposure could result in expression of the gastrin-releasing peptide (GRP) gene in NCI$\mathrm{H} 187$ cells, which it was known to be negative for under normal conditions [29]. The product of the GRP gene is a member of the bombesin family of peptides which is implicated in autocrine growth in some SCLC cells [30]. By using, as positive control, RNA extracted from the SCLC cell line NCI-H209, no GRP expression was seen in NCI-H187 cells either in the presence or absence of $0.1 \mathrm{mM}$ suramin (Figure 5).

\section{Suramin inhibits the catalytic activity of topoisomerase II in vitro}

Although suramin has been shown to have an inhibitory action on topoisomerase II of Chinese hamster cells [16], no data on human cells are available so far. We assayed the inhibitory effect of suramin on the decatenating activity of two human lung cancer cell lines, NCI-N417 and NCI-H460, which displayed a 6-fold difference in cytotoxicity. The topoisomerase II catalytic activity was assayed by decatenation of kDNA networks. kDNA is an aggregate of interlocked DNA minicircles (mostly $2.5 \mathrm{~kb}$ ) that form extremely large networks that fail to enter an agarose gel. Upon incubation with topoisomerase II, which engages DNA in a double-stranded breaking and reunion cycle, minicircular DNAs are effectively released and are able to move rapidly into the gel. Three different suramin concentrations $(10,40$ and $80 \mu \mathrm{M})$ were assayed in the inhibition of the decatenation activity. The decatenating activity induced by nuclear extracts of NCI-H460 cells was approximately comparable to that observed in NCI-N417 (Figure 6). The $\mathrm{IC}_{50}$ concentration of suramin inhibiting the decatenating activity of nuclear extracts of both cells lines was around $40 \mu \mathrm{M}$. The decatenating activity of the nuclear extracts of NCI-N417 cells was largely inhibited by 40 and $80 \mu \mathrm{M}$ suramin, as shown by the disappearance of the 2.5-kb minicircles, although a faint band was still visible at the highest protein concentrations used. A weak inhibition by $10 \mu \mathrm{M}$ suramin could only be seen at the lowest protein concentrations employed (Figure 6a). The topoisomerase II inhibitory effect of suramin was dose-dependent at concentrations in the range of $10-40 \mu \mathrm{M}$ in NCI-H460 cells (Figure 6b). 

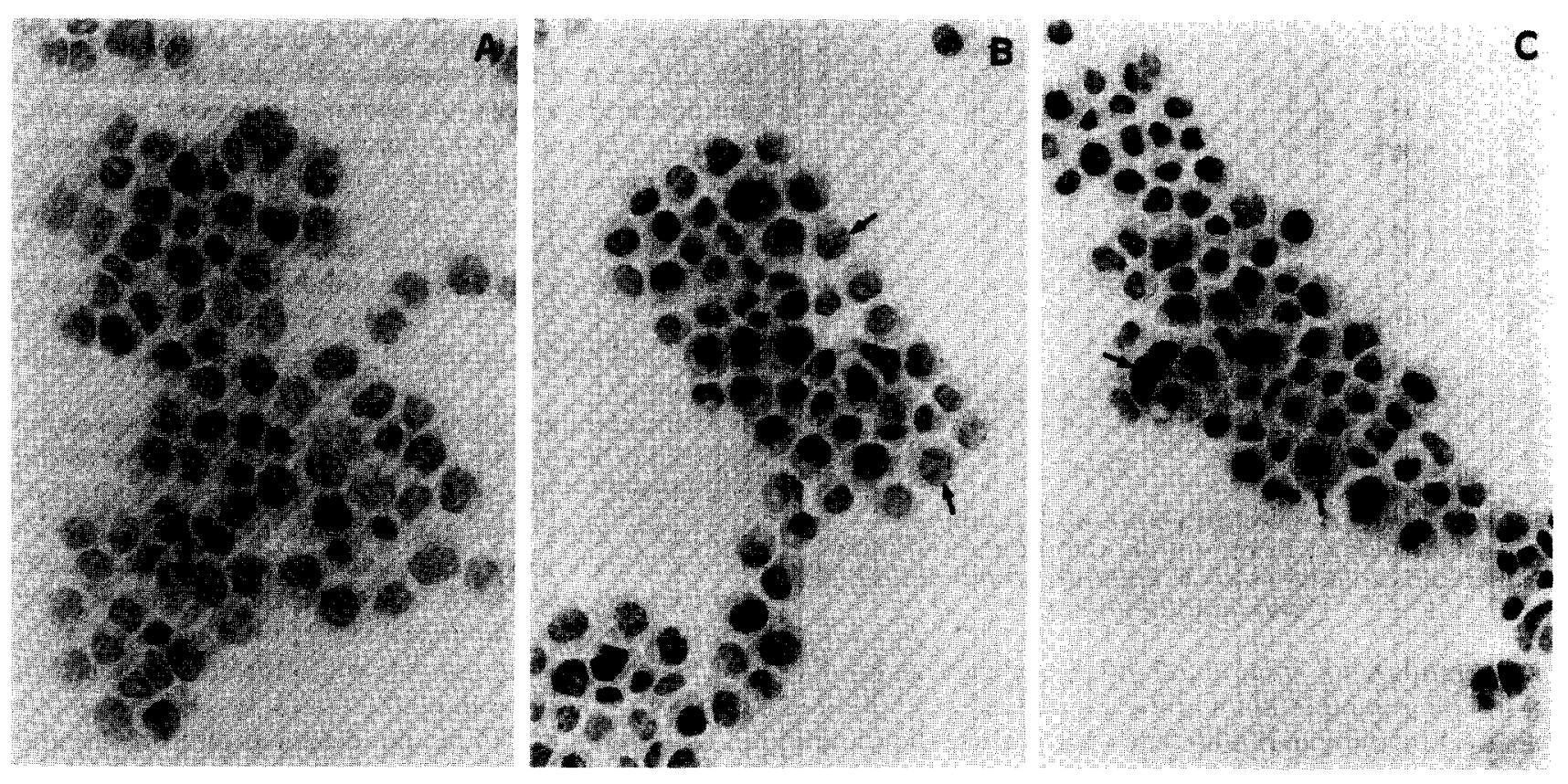

Figure 3. Ki-67 staining of NCI-H187 cells in presence (C) or absence (B) of suramin. (A) A negative control, using an irrelevant mouse IgG antibody. The different staining patterns correspond to different cell-cycle phases (see text). Cells in (C) (centre of the panel) display a more homogenous nuclear staining than cells in (B), where the staining is limited to nucleolar regions. The arrows point out the different staining patterns, as described in Results.

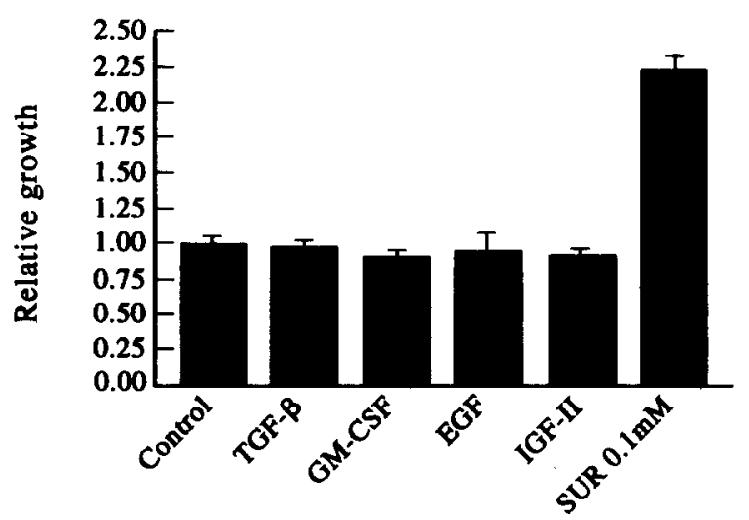

Figure 4. Relative growth of NCI-H187 cells, grown in RPMI $1640+$ $10 \%$ FCS, after 4 days of continuous exposure to different growth factors or suramin, compared with untreated control cells. See Materials and Methods for details. Experiments were performed three times; error bars are S.D. In this figure, representative concentrations of each growth factors are shown (EGF $10 \mathrm{ng} / \mathrm{ml}$; GM-CSF $1000 \mu \mathrm{M}$; TGF- $\beta 11 \mathrm{ng} / \mathrm{ml}$; IGF-II $100 \mathrm{ng} / \mathrm{ml}$ ); there was no notable difference in activity between the various concentrations of growth factors used.

\section{DISCUSSION}

Two principal mechanisms of action have been proposed for suramin activity: growth factor blockade and inhibition of cellular enzymes implicated in signal transduction pathways $[3,8,13]$. In vitro studies have shown a wide range of suramin concentrations that are required to produce $50 \%$ inhibition of growth $\left(\mathrm{IC}_{50}\right)[5,31]$.

In the lung cancer cell lines tested, the effect of suramin, although dose-dependent over the range of concentrations employed in most cell lines, was more cytostatic than cytotoxic, with no notable differences between SCLC and NSCLC cell lines. Because suramin causes dose-dependent inhibition of
MTT conversion by mitochondrial dehydrogenases, beginning approximately at $10^{-4} \mathrm{M}$, the activity shown in our assay could have been overestimated, and consequently the stimulatory effect underestimated [32]. In two SCLC cell lines, remarkable growth stimulation was observed at relatively low suramin concentrations $(5-250 \mu \mathrm{M})$. The stimulation of growth in NCI$\mathrm{H} 187$ cclls was confirmed by an increase of cells in S-phase and cells staining positive to $\mathrm{Ki}-67$, a marker of cell proliferation. The antigen recognised by the $\mathrm{Ki}-67$ monoclonal antibody accumulates predominantly during progression of cells into $S$ phase, and its rate of synthesis accelerates during the second half of this phase [33]. Our results support the fact that suramin resulted in an increase of cells located between the late $S, M$ or G2 phases in NCI-H187 cells. Although increased proliferation was observed in NCI-H187 exposed to suramin, no increase of topoisomerase II- $\alpha$ gene expression was detected by northern blotting or immunohistochemistry. This might be due to the low sensitivities of both methods in detecting relatively small differences of expression. Topoisomerase II activity can, in fact, vary from very low levels, as in quiescent cells, to high levels, as in proliferating cells [34]. Since the NCI-H187 cell line is highly proliferating and has a high topoisomerase expression [20], it might well be that small differences of expression at these higher levels could not be detected.

The stimulatory effect of suramin at relatively low concentrations has been described in several types of human tumour cell lines, including breast, prostate, squamous cell carcinoma and lung cancer cell lines [5, 27, 35-37]. In the study by Morocz and associates [37], one lung adenocarcinoma cell line out of 17 lung cancer cell lines tested was highly stimulated by suramin exposure. In this cell line, growth was stimulated by 2.6-fold, in comparison with control cells, up to a suramin concentration of $300 \mu \mathrm{g} / \mathrm{ml}$; remarkably, even at the highest suramin concentration of $1500 \mu \mathrm{g} / \mathrm{ml}$, DNA synthesis was still more than twice that of the control. 


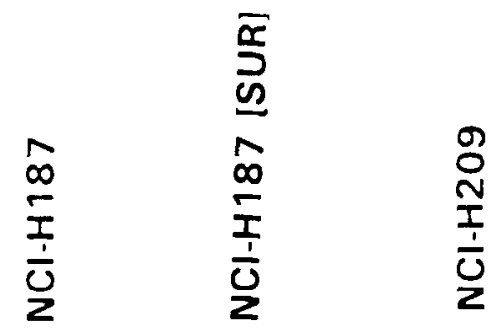

GAPDH

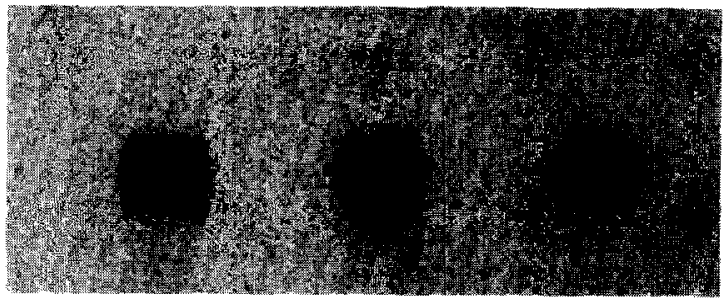

$-1.3 \mathrm{~kb}$

GRP

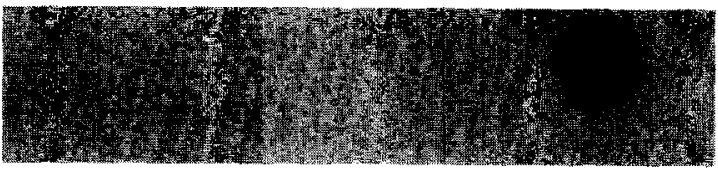

$-0.9 \mathrm{~kb}$

Figure 5. Northern blotting. Total RNA extracted from NCI-H187 cells and NCI-H187 exposed for 3 days to $0.1 \mathrm{mM}$ suramin, was run on an agarose gel. Hybridisation with cDNA probes for GRP and GAPDH (as loading control for RNA) was performed. No expression of the GRP gene could be observed in this cell line. NCI-H209 was used as positive control.

The stimulatory effect of low suramin concentrations on the proliferation of cancer cells, and in particular of lung cancer cells, should be considerecl seriously in planning clinical trials with this drug. The concentrations of suramin found to stimulate growth in cell lines are, in fact, easily reached after suramin administration has been stopped [38]. As the half-life of suramin in plasma is exceptionally long (around 40-50 days) [38], the duration of a relatively low plasma concentration, able to stimulate growth in some cell lines, can be sufficiently long to provoke tumour growth acceleration.

The stimulation of growth has been shown to be mediated through the EGF receptor (EGFR) in the KB cell line [27], the cells being induced to release membrane-bound $\mathrm{TGF} \alpha$, resulting in activation of EGFR. Moreover, it was recently reported that a large propurtion of a broad panel of SCLC cell lines express the EGFR [28].

In the human SCLC cell line, NCI-H187, no effect was observed by EGF, GM-CSF, TGF- $\beta$ or IGF-II either alone or in combination with suramin. EGF and IGF-II did not display any effect either alone or in combination with suramin on NCIN417 cells growing in 10\% FCS or in HITES serum-free medium. NCI-N417 cells are known to express EGFR [28]. EGF, GM-CSF and IGF-lII have been shown to be able to modulate cell growth in lurig cancer cell lines [17, 39, 40] and TGF- $\beta$ has recently been shown to be expressed in a number of SCLC cell lines, along with its receptor [41]. The IGF-II gene is more widely expressed than the IGF-I gene in human lung cancer cell lines [40].

The expression of GRP was not elicited by exposure of NCIH187 cells to suramin. GRP' expression can be increased in cell lines which already express this gene, for example, after exposure to laminin, the major component of the extracellular matrix
[42]. The NCI-H187 cell line, however, does not constitutively express GRP even when assessed by sensitive methods [29].

Since suramin is highly protein bound [43], mainly to albumin [44], and it has been suggested that suramin inhibitory effects are dependent on the free suramin concentrations [21], we performed additional experiments in NCI-N417 cells adapted to grow in different FCS concentrations and in HITES serum-free medium. Interestingly, suramin was 18 times more cytotoxic in NCI-N417 cells growing in $2 \%$ FCS than in $10 \%$ FCS, but only 3.3 times more cytotoxic when grown in HITES serum-free medium. The higher IC 50 values obtained in cells grown in $10 \%$ FCS and in HITES were due to a great degree to the stimulatory effect that suramin had at low concentrations on these cells. Concentrations of serum might be important, as stimulation of cell proliferation was observed in NCI-N417 growing in 10\% FCS and was greatest in HITES serum-free medium. It might be that critical concentrations of an as yet unidentified 'growth factor' contained in FCS may be necessary to potentiate the action of suramin on proliferation of cells. This factor, together with the differential cytotoxicity based on protein concentration in the medium, may be responsible for the modulation of the effects on the growth of these cell lines. The addition of BSA, although producing an increase in the $\mathrm{IC}_{50}$ in HITES-grown NCI-N417 cells, as shown for other cell lines [21], did not alter the stimulatory effect of suramin at low concentrations, indicating that the binding might be less relevant at these relatively low concentrations.

However, it should be considered that the concentration of proteins contained in RPMI 1640 plus $10 \%$ FCS is only approximately $10 \%$ of that normally present in human blood. Taking this into consideration and the fact that in patients an optimal concentration in plasma of suramin is between 150 and 
(a)

A

$\begin{array}{llllll}1 & 2 & 3 & 4 & 5 & 6\end{array}$

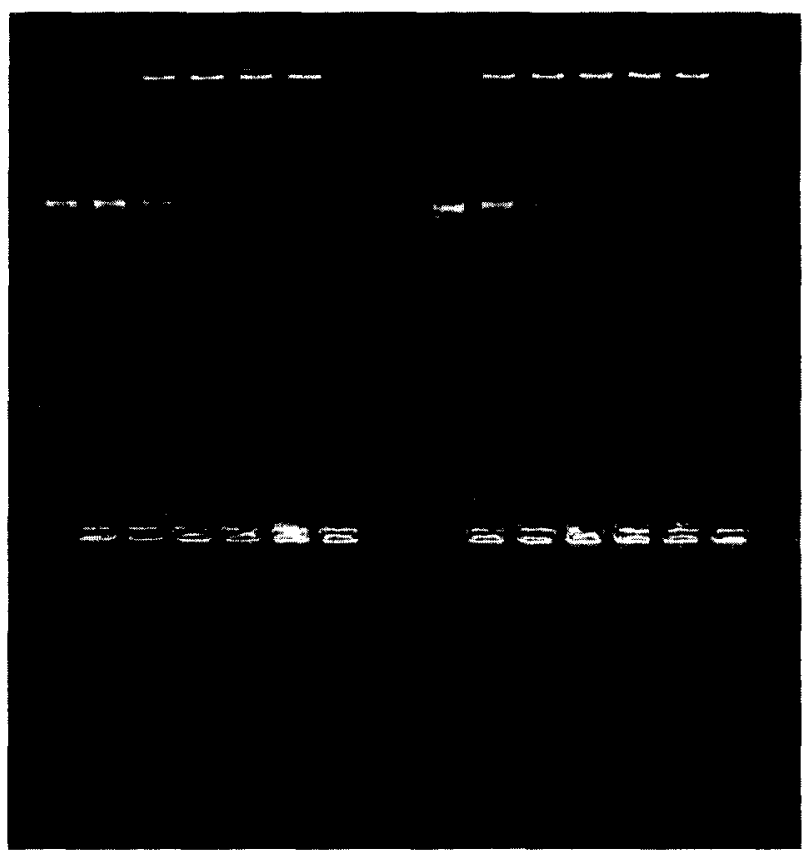

$\begin{array}{llllll}1 & 2 & 3 & 4 & 5 & 6\end{array}$

C
B

\section{6}

123456

(b)

A

B

C

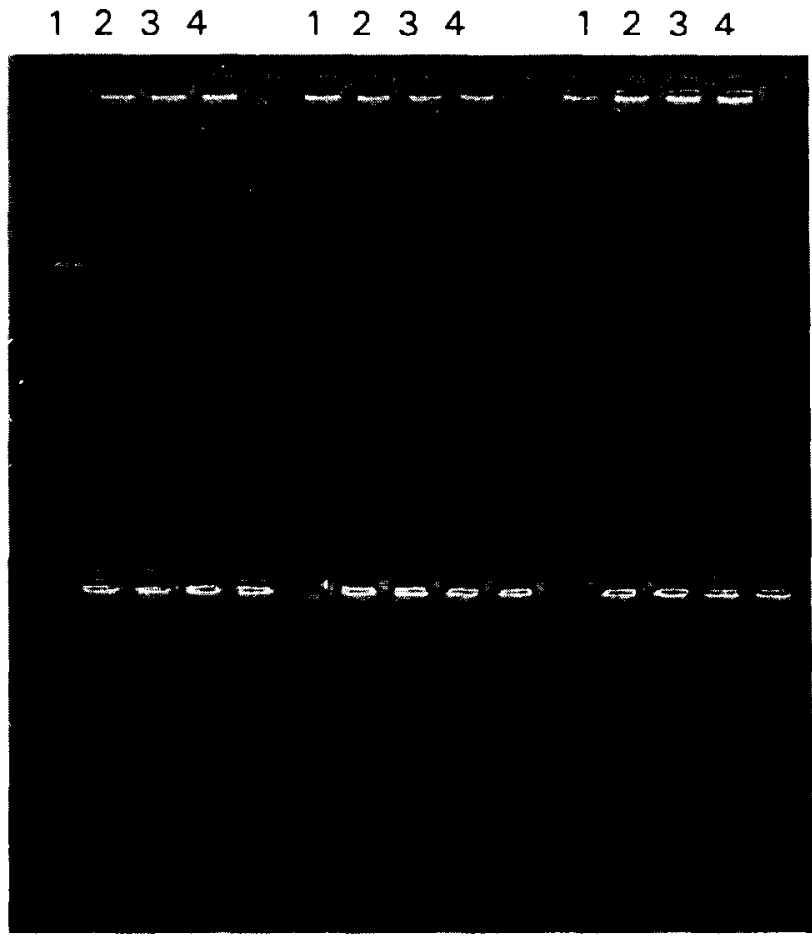

1234

1234

1234

D

E

F

Figure 6(a). k-DNA decatenation assay of nuclear extracts of NCI-N417 cell line. (A-D) Different suramin concentrations. (A) Control (without suramin); (B) suramin $10 \mu \mathrm{M}$; (C) suramin $40 \mu \mathrm{M}$; (D) suramin $80 \mu \mathrm{M}$. Lanes 1-6 have different protein concentrations. Lane 1:

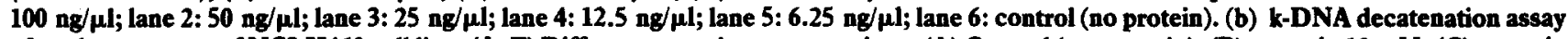
of nuclear extracts of NCI-H460 cell line. (A-F) Different suramin concentrations. (A) Control (no suramin); (B) suramin $10 \mu M$; (C) suramin $20 \mu \mathrm{M}$; (D) suramin $30 \mu \mathrm{M}$;(E) suramin $40 \mu \mathrm{M}$; (F) suramin $80 \mu \mathrm{M}$. Lanes 1-4 have different protein concentrations. Lane 1: $50 \mathrm{ng} / \mu \mathrm{l} ;$ lane 2: $25 \mathrm{ng} / \mu \mathrm{l}$; lane 3: $12.5 \mathrm{ng} / \mu \mathrm{l}$; lane 4: control (no protein).

$250 \mathrm{mg} / \mathrm{l}(100 \mu \mathrm{M}=143 \mathrm{mg} / \mathrm{l})$, it can be expected that only in a minority of cases will it be possible to reach a plasma concentration able to inhibit growth of lung cancer cells. In fact, only in one cell line that we tested were such concentrations able to cause $50 \%$ growth inhibition.

Suramin inhibited topoisomerase II activities extracted from two human lung cancer cell lines. However, despite a 6-fold difference in suramin cytotoxicity between the two cell lines tested, there was no appreciable difference in inhibition of decatenating activity by suramin. Although inhibition of topoisomerase II activity occurs, it remains to be established whether suramin cytotoxic activity is topoisomerase II mediated. In contrast to other topoisomerase II inhibitors, suramin has not been shown to induce DNA fragmentation [16], and DNA cleavage appears to be an important step in topoisomerase IImediated cell kill induced by topoisomerase II inhibitors [45]. Furthermore, in the panel of studied cell lines, no correlation was observed between levels of expression of topoisomerase II [20] and cytotoxicity to suramin, in contrast to the rather good correlation with other topoisomerase II inhibitors (e.g. doxorubicin, etoposide). Moreover, no correlation between suramin cytotoxicity and cytotoxicity to other topoisomerase II inhibitors was observed in this study [20]. Factors other than topoisomerase inhibition may be responsible for this lack of correlation.
In conclusion, a wide range of suramin concentrations induced growth inhibition of human lung cancer cell lines, but only in one was the $\mathrm{IC}_{\mathrm{S}}$ in the range of concentrations that can be reached in plasma of patients. Although suramin inhibited topoisomerase II activity in the human cell lines tested, this might represent a secondary mechanism of suramin cytotoxicity. As stimulatory action was observed with suramin in two cell lines, properly designed clinical trials are mandatory to correctly assess the anti-tumour activity of suramin and its possible accelerating effect on tumour growth. The mechanism employed by suramin to stimulate growth of some lung cancer cell lines remains to be elucidated.

1. Hawking F. Suramin: with special reference to onchocerciasis. Adv Pharmacol Chemother 1978, 15, 283-322.

2. Eisenberger MA, Fontana JA. Suramin, an active nonhormonal cytotoxic drug for treatment of prostate cancer: compelling reasons for testing in patients with hormone-refractory breast cancer. $7 \mathrm{Natl}$ Cancer Inst 1992, 84, 3-5.

3. Coffey RJ, Leof EB, Shipley GD, Moses HL. Suramin inhibition of growth factor receptor binding and mitogenicity in AKR-2B cells. $\mathcal{J}$ Cell Phys 1987, 132, 143-148.

4. Hosang $M$. Suramin binds to platelet-derived growth factor and inhibits its biological activity. F Cell Biochem 1985, 29, 265-273.

5. Olivier S, Formento JL, Fischel JL, Etienne MC, Milano G. 
Epidermal growth factor expression and suramin cytotoxicity in vitro. Eurf Cancer 1990, .26, 867-871.

6. Kim JH, Sherwood ER, Sutkowski DM, Lee C, Kozlowski J. Inhibition of prostatic tumor cell proliferation by suramin: alterations in TGF alpha-mediated autocrine growth regulation and cell cycle distribution. $f$ Urol 1991, 146, 171-176.

7. Pollak M, Richard $M$. Suramin blockade of insulinlike growth factor I-stimulated proliferation of human osteosarcoma cells. $\mathcal{f}$ Natl Cancer Inst 1990, 82, 1349-1352.

8. Minniti CP, Maggi M, Helman LJ. Suramin inhibits the growth of human rhabdomyosarcoma by interrupting insulin-like growth factor II autocrine growth loop. Cancer Res 1992, 52, 1830-1835.

9. Mills GB, Zhang N, May C, Hill M, Chung A. Suramin prevents binding of interleukin-2 to its cell surface receptor: a possible mechanism of immunosuppression. Cancer Res 1990, 50, 3036-3042.

10. Zabrenetzky VS, Kohn EC, Roberts DD. Suramin inhibits lamininand thrombospondin-mediated melanoma cell adhesion and migration and binding of this adhesive proteins to sulfatide. Cancer Res 1990, 50, 5937-5942.

11. Nakajima M, Dechavigny A, Johnson CE, Hamada J, Stein C, Nicolson G. Suramin a potent inhibitor of melanoma heparanase and invasion. 7 Biol Chem 1991, 266, 9661-9666.

12. Hensey CE, Boscoboinik D, Azzi A. Suramin, an anti-cancer drug, inhibits protein kinase $\mathrm{C}$ and induces differentiation in neuroblastoma cell clone 1NB2A. FEBS Lett 1989, 258, 156-158.

13. Kopp R, Pfeiffer A. Suraunin alters phosphoinositide synthesis and inhibits growth factor receptor binding in HT-29 cells. Cancer Res $1990,50,6490-6496$.

14. Declercq E. Suramin: a potent inhibitor of the reverse transcriptase of RNA tumor viruses. Cincer Lett 1979, 8, 9-22.

15. Jindal HK, Anderson CW, Davis RG, Vishwanatha JK. Suramin affects DNA synthesis in HeLa cells by inhibition of DNA polymerases. Cancer Res 1990, 50, 7754-7757.

16. Bojanowski K, Lelievre S, Markovits J, Couprie J, JacqueminSablon A, Kragh Larsen A. Suramin is an inhibitor of DNA topoisomerase II in vitro and in Chinese hamster fibrosarcoma cells. Proc Natl Acad Sci USA 1992, 89, 3025-3029.

17. Ginsberg RJ, Kris MG, Armstrong JG. Cancer of the lung. In DeVita VT, Hellman S, Fosenberg SA, eds. Cancer, Principles and Practice of Oncology, 4th edition. Philadelphia, J.B. Lippincott Company, 1993, 673-758.

18. Simms E, Gazdar AF, Atrams PG, Minna JD. Growth of human small-cell (oat-cell) carcinoma of the lung in serum-free growth factor supplemented mcdium. Cancer Res 1980, 40, 4356-4363.

19. Keepers YP, Pizao PE, P'etrs GJ, Van Ark-Otte J, Winograd B, Pinedo HM. Comparison of the sulforhodamine B protein and tetrazolium (MTT) assays for in vitro chemosensitivity testing. Eur 7 Cancer 1991, 27, 897-900.

20. Giaccone G, Gazdar AF, Beck H, Zunino F, Capranico G. Multidrug sensitivity phenorype of human lung cancer cells associated with topoisomerase II expression. Cancer Res 1992, 52, 1666-1674.

21. Lopez Lopez R, Peters GJ, Van Loenen AC, et al. The effect of schedule, protein binding and growth factors on the activity of suramin. Int $\mathcal{F}$ Cancer 1992, 51, 921-926.

22. de Jong $S$, Zijstra JG, de Vries EGE, Mulder NH. Reduced DNA topoisomerase II activity and drug-induced DNA cleavage activity in an adriamycin-resistant human small cell lung carcinoma cell line. Cancer Res 1990, 50, 304-309.

23. Negri C, Chiesa R, Cerino A, et al. Monoclonal antibodies to human DNA topoisomerase I and the two isoforms of DNA topoisomerase II: 170 - and $180-\mathrm{kDa}$ isozymes. Exp Cell Res 1992, 200, 452-459.

24. Zini N, Martelli AM, Sabatelli P, Santi S, Negri C, Astaldi Ricotti GCB. The $180-\mathrm{kDa}$ isoform of topoisomerase II is localized in the nucleolus and belongs to the structural elements of the nucleolar remnant. Exp Cell Res 1992, 200, 460-466.

25. Sambrook J, Fritsch EF, Maniatis T. Molecular Cloning: A Laboratory Manual. Cold Spring Harbor, New York, Cold Spring Harbor Laboratory Press, 1989.

26. Van Dierendonck JH, Keijzer R, Van de Velde CJH, Cornelisse CJ. Nuclear distribution of the $\mathrm{Ki}-67$ antigen during the cell cycle: comparison with growth fraction in human breast cancer cells. Cancer Res 1989, 49, 2999-3006.
27. Cardinali M, Sartor O, Robbins KC. Suramin, an experimental chemotherapeutic drug, activates the receptor for epidermal growth factor and promotes growth of certain malignant cells. $\mathcal{J} \mathrm{Clin} I$ nvest. $1992,89,1242-1247$.

28. Damstrup L, Rygaard K, Spang-Thomsen $M$, Skovgaard $H$. Expression of the epidermal growth factor receptor in human small cell lung cancer cell lines. Cancer Res 1992, 52, 3089-3093.

29. Giaccone G, Battey J, Gazdar AF, Oie H, Draoui M, Moody T. Neuromedin B is present in lung cancer cell lines. Cancer Res 1992, 52, 2732s-2736s.

30. Cuttitta F, Carney DN, Mulshine J, et al. Bombesin-like peptides can function as autocrine growth factors in human small cell lung cancer. Nature 1985, 316, 823-826.

31. Taylor CW, Lui R, Fanta P, Salmon SE. Effects of Suramin on in vitro growth of fresh human tumors. 7 Natl Cancer Inst 1992, 84, $489-494$.

32. Rago R, Mitchen J, Cheng A-L, Oberley T, Wilding G. Disruption of cellular energy balance by suramin in intact human prostatic carcinoma cells, a likely antiproliferative mechanism. Cancer Res $1991,51,6629-6635$.

33. Bruno S, Darzynkiewicz Z. Cell cycle dependent expression and stability of the nuclear protein detected by Ki-67 antibody in HL60 cells. Cell Prolif 1992, 25, 31-40.

34. Heck MMS, Hittelman WN, Earnshaw WC. Differential expression of DNA topoisomerases I and II during the eukaryotic cell cycle. Proc Natl Acad Sci USA 1988, 85, 1086-1090.

35. Michel $P$, Van Velthoven $R$, Petein $M$, et al. Influence of suramin alone or in combination with DHT and PDGF on the cell proliferation of benign and malignant human prostatic tissues in organ cultures. Anticancer Res 1991, 11, 2075-2078.

36. Foekens JA, Sieuwerts AM, Stuurman-Smeets EMJ, Dorssers LCJ, Berns EMJJ, Klijn JGM. Pleiotropic action of suramin on the proliferation of human breast-cancer cells in vitro. Int 7 Cancer 1992, $51,439-444$

37. Morocz IA, Lauber B, Schmitter D, Stahel RA. In vitro effect of suramin on lung tumour cells. Eur f Cancer 1993, 29A, 245-247.

38. Van Rijswijk REN, Van Loenen AC, Wagstaff J, et al. Suramin rapid loading and weekly maintenance regimens for cancer patients. 7 Clin Oncol 1992, 10, 1788-1794.

39. Ruff MR, Farrar WL, Pert CB. Interferon gamma and granulocyte/ macrophage colony-stimulating factor inhibit growth and induce antigens characteristic of mycloid differentiation in small cell lung cancer. Proc Natl Acad Sci USA 1986, 83, 6613-6617.

40. Reeve JS, Brinkman A, Hughes S, Mitchell J, Schwonder J, Blehen NM. Expression of insulin-like growth factor (IGF) and IGFbinding protein genes in human lung tumor cell lines. $\mathcal{F}$ Natl Cancer Inst 1992, 84, 628-634.

41. Damstrup L, Rygaard K, Spang-Thomsen M, Skovgaard-Poulsen H. Expression of transforming growth factor beta (TGF beta) receptors and expression of TGF beta 1 , TGF beta 2 and TGF beta 3 in human small cell lung cancer cell lines. $\mathrm{Br} F$ Cancer 1993, 67, $1015-1021$.

42. Giaccone G, Broers J, Jensen S, Fridman RI, Linnoila R, Gazdar AF. Increased expression of differentiation markers can accompany laminin-induced attachment of small cell lung cancer. $\mathrm{Br} f$ Cancer $1992,66,488-495$

43. Collins JM, Klecker RW, Yarchoan R, et al. Clinical pharmacokinetics of suramin in patients with HTLV-III/LAV infection. $\mathcal{F}$ Clin Pharmacol 1986, 26, 22-26.

44. Bos OJM, Vansterkenburg ELM, Boon JPCI, Fischer MJE, Wilting J, Janssen LHM. Location and characterization of the suramin binding sites of human serum albumin. Biochem Pharmacol 1990, 40, 1595-1599.

45. Macdonald TL, Lehnert EK, Loper JT, Chow KC, Ross WE. On the mechanism of interaction of DNA topoisomerase II with chemotherapeutic agents. In Potmesil M, Kohn KW, eds, DNA Topoisomerases in Cancer. New York, Oxford University Press, $1991,199-214$

Acknowledgements - G.J. Rubio is the recipient of a fellowship from the National Academy of Mcdicine of Buenos Aires, Argentina. We gratefully thank Dr G. Astaldi-Ricotti for provision of monoclonal antibodies to topoisomerases. 